\title{
Central precocious puberty in a patient with X-linked adrenal hypoplasia congenita and Xp21 contiguous gene deletion syndrome
}

\author{
Ji Won Koh, MD', \\ So Young Kang, $\mathrm{MD}^{1}$, \\ Gu Hwan Kim, PhD², \\ Han Wook Yoo, MD, PhD², \\ Jeesuk Yu, MD, PhD ${ }^{1}$ \\ ${ }^{1}$ Department of Pediatrics, Dankook \\ University College of Medicine, \\ Cheonan, ${ }^{2}$ Medical Genetics Center, \\ Asan Medical Center, Seoul, Korea
}

X-linked adrenal hypoplasia congenita is caused by the mutation of DAX-1 gene (dosage-sensitive sex reversal, adrenal hypoplasia critical region, on chromosome $X$, gene 1), and can occur as part of a contiguous gene deletion syndrome in association with glycerol kinase (GK) deficiency, Duchenne muscular dystrophy and X-linked interleukin-1 receptor accessory protein-like 1 (IL 1RAPL 1) gene deficiency. It is usually associated with hypogonadotropic hypogonadism, although in rare cases, it has been reported to occur in normal puberty or even central precocious puberty. This study addresses a case in which central precocious puberty developed in a boy with X-linked adrenal hypoplasia congenita who had complete deletion of the genes DAX-1, GK and IL IRAPL1 (Xp21 contiguous gene deletion syndrome). Initially he was admitted for the management of adrenal crisis at the age of 2 months, and managed with hydrocortisone and florinef. At 45 months of age, his each testicular volumes of $4 \mathrm{~mL}$ and a penile length of $5 \mathrm{~cm}$ were noted, with pubic hair of Tanner stage 2 . His bone age was advanced and a gonadotropin-releasing hormone $(\mathrm{GnRH})$ stimulation test showed a luteinizing hormone peak of $8.26 \mathrm{IU} / \mathrm{L}$, confirming central precocious puberty. He was then treated with a GnRH agonist, as well as steroid replacement therapy. In Korea, this is the first case of central precocious puberty developed in a male patient with X-linked adrenal hypoplasia congenita.

Keywords: X-linked adrenal hypoplasia congenita, Nuclear Receptor DAX-1, Precocious puberty, Central

\section{Introduction}

Adrenal hypoplasia congenita (AHC) is a developmental disorder of the human adrenal gland which results in significant hormonal deficiencies and is lethal if untreated. Deletions or mutations of the gene $D A X-1$ (dosage-sensitive sex reversal, adrenal hypoplasia critical region, on chromosome $\mathrm{X}$, gene 1), that is now designated NROB1 (nuclear receptor subfamily 0 , group $\mathrm{B}$, member 1), cause the $\mathrm{X}$-linked form of $\mathrm{AHC}^{1)}$. The $D A X$-1 gene, located on Xp21, consists of 2 exons. It can also occur as a part of contiguous gene deletion syndrome together with glycerol kinase $(G K)$ deficiency and/or Duchenne muscular dystrophy $(D M D)^{2)}$. It is classically known to cause hypogonadotropic hypogonadism as a puberty disorder ${ }^{3)}$. However, few cases have reported its association with central precocious puberty even though its mechanism has not been identified ${ }^{4,5)}$.

Here we report a male patient with X-linked AHC and contiguous gene deletion of $D A X-1$, $G K$ and ILIRAPL1 who developed central precocious puberty instead of hypogonadotropic hypogonadism.
Received: 29 May, 2013

Accepted: 25 June, 2013

Address for correspondence: Jeesuk Yu, MD, PhD

Department of Pediatrics, Dankook University College of Medicine, 119 Dandae-ro, Dongnam-gu, Cheonan 330-997,

Korea

Tel: +82-41-550-3938

Fax: +82-41-565-6167

E-mail:dryujs@dankook.ac.kr
This is an Open Access article distributed under the terms of the Creative Commons Attribution Non-Commercial License (http:// creativecommons.org/licenses/by-nc/3.0) which permits unrestricted non-commercial use, distribution, and reproduction in any medium, provided the original work is properly cited.
ISSN: 2287-1012(Print) ISSN: 2287-1292(Online) 


\section{Case report}

The 9 year and 4 months old boy who has been diagnosed as having primary adrenal insufficiency was noticed to have enlarged testes at the age of 45 months. He was born at $41^{+3}$ weeks' gestation, weighing $3.4 \mathrm{~kg}$ by spontaneous vaginal delivery. He was presented with poor weight gain and dark skin pigmentation on whole body at the age of 2 months. On admission, his initial sodium level was $118 \mathrm{mEq} / \mathrm{L}$, potassium level was $5.6 \mathrm{mEq} / \mathrm{L}$ and urine sodium was $92 \mathrm{mEq} / \mathrm{L}$, suggesting mineralocorticoid deficiency. The urinary level of 17-ketosteroid collected for 24 hours was low as $0.47 \mathrm{mg} /$ day (reference, less than $0.5 \mathrm{mg} /$ day). Other initial results before treatment were as followed: 17 -hydroxyprogesterone (17-OHP), $20.5 \mathrm{ng} / \mathrm{mL}$ (reference, less than $3 \mathrm{ng} / \mathrm{mL}$ ); cortisol, $43.4 \mu \mathrm{g} /$ $\mathrm{dL}$ (reference, 2.8-23 $\mu \mathrm{g} / \mathrm{dL}$ ); adrenocorticotropic hormone (ACTH), $250 \mathrm{pg} / \mathrm{mL}$ (reference, $10-60 \mathrm{pg} / \mathrm{mL}$ ); renin, $0.63 \mathrm{ng} /$ $\mathrm{mL} / \mathrm{hr}$ (reference, $2.35-37 \mathrm{ng} / \mathrm{mL} / \mathrm{hr}$ ) (Table 1). Under the impression of congenital adrenal insufficiency, he started taking hydrocortisone and florinef. During follow-up, he had several episodes of admission due to adrenal crisis associated with febrile illnesses.

When he became 8 months of age, he could only roll over. He couldn't sit alone and had difficulty in creeping. We performed Bayley developmental test three times (at the age of 13 months, 25 months, and 40 months) and the results showed persistent severe mental retardation.

When he was 45 months, his height was $110.9 \mathrm{~cm}$ (z score, 2.17 ) and his weight was $19.2 \mathrm{~kg}$ ( $\mathrm{z}$ score, 1.40 ). His testes were $4 \mathrm{~mL}$ in volume bilaterally with Tanner stage 2 pubic hair. Bone age acceleration was also observed (chronologic age 45 months, bone age 66 months). Since gonadotropin-releasing hormone $(\mathrm{GnRH})$ stimulation test showed the luteinizing hormone (LH) peak of $8.26 \mathrm{IU} / \mathrm{L}$ (Table 2), we started GnRH agonist treatment under the diagnosis of central precocious puberty.

At 55 months of age, we performed ACTH stimulation test because of his atypical manifestations such as mental retardation and the initial relatively high cortisol level which are not usually found in congenital adrenal hyperplasia. In ACTH stimulation test, the peak cortisol level at 60 minutes was 7.40 $\mu \mathrm{g} / \mathrm{dL}$, suggesting cortisol deficiency. The level of $17-\mathrm{OHP}$ was

\section{Table 2. Results of GnRH stimulation test}

\begin{tabular}{lccc}
\hline & 0 min & 30 min & 60 min \\
\hline $\begin{array}{l}\text { At } 46 \text { months of age } \\
\text { LH (IU/L) }\end{array}$ & 0.48 & $5.15^{*}$ & $8.26^{*}$ \\
FSH (IU/L) & 1.44 & 2.43 & 2.86 \\
At 50 months of age ${ }^{\dagger}$ & & & \\
LH (IU/L) & 0.33 & 0.88 & 0.72 \\
FSH (IU/L) & 1.56 & 2.01 & 1.84 \\
At 63 months of age & & & \\
LH (IU/L) & 3.59 & $7.61^{*}$ & $8.38^{*}$ \\
FSH (IU/L) & 3.73 & $4.13^{*}$ & $4.48^{*}$ \\
\hline
\end{tabular}

$\mathrm{GnRH}$, gonadotropin-releasing hormone; LH, luteinizing hormone; FSH, follicle stimulating hormone.

${ }^{*} \mathrm{GnRH}$ stimulation test showed increased LH and FSH levels at 30 minutes and 60 minutes of the test. ${ }^{\dagger}$ At 50 months, suppressed $\mathrm{LH}$ responses were detected after the treatment with $\mathrm{GnRH}$ agonist. ${ }^{\ddagger} \mathrm{GnRH}$ agonist treatment was stopped from 58 months to 63 months and restarted after third GnRH stimulation test.

Table 1. Laboratory results and medication dosages during follow-up

\begin{tabular}{|c|c|c|c|c|c|c|c|}
\hline \multirow{2}{*}{ Variable } & \multicolumn{7}{|c|}{ Age (mo) } \\
\hline & 2 & 14 & 25 & 46 & 63 & 80 & 100 \\
\hline $\mathrm{Na} / \mathrm{K}$ (mmol/L) & $118^{*} / 5.6$ & $135 / 4.3$ & $125^{*} / 4.9$ & $136 / 4.9$ & & & $141 / 4.3$ \\
\hline Glucose (mg/dL) & 115 & 102 & 59 & $28^{*}$ & & & 89 \\
\hline AST (IU/L) & 65 & 36 & 45 & 35 & 19 & & 15 \\
\hline ALT (IU/L) & 52 & 18 & 16 & 31 & 10 & & 9 \\
\hline TG (mg/dL) & & & & & & 370 & 416 \\
\hline 17-OHP (ng/mL) & 20.5 & 0.47 & & & & & \\
\hline Cortisol ( $\mu \mathrm{g} / \mathrm{dL})$ & 43.4 & 23.09 & & & & 16.4 & 22.3 \\
\hline ACTH $(p g / m L)$ & 250.4 & & 725.6 & & 73.4 & 1.8 & 3.54 \\
\hline Renin (ng/mL/hr) & 0.64 & 1.82 & & & 3.55 & 1.25 & 0.67 \\
\hline Aldosterone (pg/mL) & 457.7 & & & & & & 5 \\
\hline $\mathrm{LH}(\mathrm{mlU} / \mathrm{mL})$ & & 1.81 & & & 3.59 & 0.34 & 0.14 \\
\hline $\mathrm{FSH}(\mathrm{mIU} / \mathrm{mL})$ & & 1.06 & & & 3.73 & 0.49 & 0.9 \\
\hline Testosterone (ng/mL) & & 1.93 & & & 1.18 & 0.11 & 0.2 \\
\hline DHEA-S $(\mu \mathrm{g} / \mathrm{dL})$ & & & & & 4.0 & $<5.0$ & 2 \\
\hline $\mathrm{HC}$ dosage ${ }^{\dagger}, \mathrm{mg} /$ day $\left(\mathrm{mg} / \mathrm{m}^{2} /\right.$ day $)$ & $6(24.6)$ & $10(19.6)$ & $10(16.5)$ & $15(19.5)$ & $22.5(24.2)$ & $27.5(25.1)$ & $27.5(21.2)$ \\
\hline Florinef (mg) & 0.1 & 0.1 & 0.1 & 0.1 & 0.1 & 0.1 & 0.1 \\
\hline
\end{tabular}

AST, aspartate aminotransferase; ALT, alanine aminotransferase; TG, triglyceride; 17-OHP, 17-hydroxyprogesterone; ACTH, adrenocorticotropic hormone; LH, luteinizing hormone; FSH, follicle stimulating hormone; DHEA-S, dehydroepiandrosterone sulfate; HC, hydrocortisone.

*Adrenal crises with hyponatremia and hypoglycemia were observed during follow-up. 'Dosage of HC were recorded as mg/day and mg/ $\mathrm{m}^{2} /$ day in parentheses. 
also lower than normal and the ratio of $17-\mathrm{OHP} /$ cortisol at 60 minutes was less than 0.1 which was not compatible with congenital adrenal hyperplasia due to 21 -hydroxylase deficiency (Table 3).

Genetic study showed $D A X-1$ deletion, confirming X-linked AHC. Deletion of the genes of $G K$ and ILIRAPL1 was also observed, which we call 'Xp21 contiguous gene deletion syndrome'. Deletion of ILIRAPLI gene is known to cause $\mathrm{X}$-linked intellectual disability. His younger brother who was born one year after him, was also diagnosed as Xp21 contiguous gene deletion syndrome with same mutation.

It is unusual to have central precocious puberty in the case with $D A X-1$ deficiency. Subcutaneous injection of $\mathrm{GnRH}$ agonist (leuprolide acetate) started at 46 months. Follow-up of GnRH stimulation test at 50 months showed suppressed LH responses. After 1 year of GnRH agonist therapy, we stopped GnRH agonist injection for 6 months and reevaluated the pubertal status. On repeated GnRH stimulation test, the peak LH level showed pubertal level, therefore we restarted the GnRH agonist therapy.

For evaluating GK status, we checked urine glycerol and it was slightly increased $(\mathrm{Cr}, 10.58 \mathrm{mmol} / \mathrm{mol}$; reference, not detected). Hypertriglyceridemia of $370 \mathrm{mg} / \mathrm{dL}$ (reference, 31-108 mg/dL) was also consistent finding to GK deficiency (Table 1).

Now he is 9 year and 4 months old (bone age, 11 year and 2 months) with height of $143.8 \mathrm{~cm}$ (z score, 1.63), weighing 45

Table 3. Result of ACTH stimulation test

\begin{tabular}{lccc}
\hline & 0 min & 30 min & 60 min \\
\hline Cortisol $(\mu \mathrm{g} / \mathrm{dL})$ & 7.99 & 5.99 & 7.40 \\
$17-\mathrm{OHP}(\mathrm{ng} / \mathrm{mL})$ & $<0.1$ & $<0.1$ & $<0.1$ \\
\hline
\end{tabular}

$\mathrm{ACTH}$, adrenocorticotropic hormone; 17-OHP, 17-hydroxyprogesterone. kg (z score, 1.61) (Fig. 1). The improvement in growth z score based on bone age reflects that he is a good responder in $\mathrm{GnRH}$ agonist therapy as well as hydrocortisone $\left(20.5 \mathrm{mg} / \mathrm{m}^{2} /\right.$ day $)$ and florinef $(0.1 \mathrm{mg} /$ day $)$ medication.

\section{Discussion}

$\mathrm{X}$-linked AHC is one of the most common causes of primary adrenal failure. It was initially described by Sikl ${ }^{6)}$ in 1948. In 1994, mutation in the nuclear receptor gene $D A X$ 1 was reported as the causative genetic abnormality. Patients with X-linked AHC frequently develop severe salt-wasting with glucocorticoid and mineralocorticoid insufficiency in infancy and it is generally related to hypogonadotropic hypogonadisim ${ }^{3,7)}$. This is because the adrenal glands lack the permanent adult cortical zone. The remaining cells are termed "cytomegalic" because they are larger than typical fetal adrenal cells and contain characteristic nuclear inclusions from cytoplasmic invaginations ${ }^{8)}$.

It is useful to differentiate 21-hydroxylase deficiency (congenital adrenal hyperplasia) with X-linked AHC because each could have different clinical courses as well as different mode of inheritance.

In our case, initial renin level was decreased which was not compatible with typical finding in untreated X-linked AHC patient. This was because the blood test was done after 2 hours of hydration.

Gene analysis was done because of atypical developmental delay and decreased serum level of 17-hydroxyprogesterone on ACTH stimulation test.

Genetic test revealed Xp21 contiguous gene deletion syndrome at Xp21 locus which involved $D A X-1, G K$, and

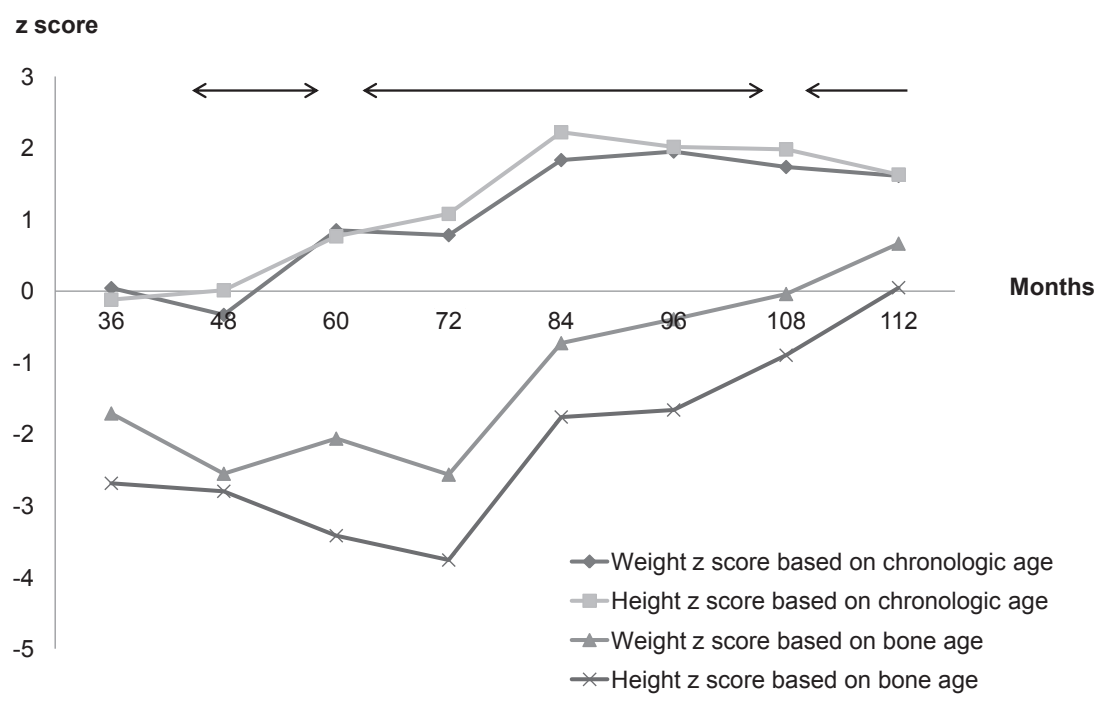

Fig. 1. Changes of height and weight z scores according to chronologic and bone ages. Initially, weight and height $z$ scores based on bone age were lower than average, but both of them are now in around average levels. Arrows represent the period of gonadotropin-releasing hormone therapy which are from 46 months to 57 months, from 64months to 103 months, and from 110 months till now. 


\section{ILIRAPL1 genes.}

$\mathrm{X}$-linked AHC is usually associated with hypogonadotropic hypogonadism because $D A X-1$ mutations probably impair gonadotropin production by acting at both the hypothalamic and pituitary levels ${ }^{9)}$. But the onset of puberty could be variable from arrested or absent puberty ${ }^{10,11)}$ to precocious puberty ${ }^{4,5,12)}$. Precocious puberty is generally defined as the appearance of secondary sex characteristics before age 8 years in girls and before 9 years in boys ${ }^{13)}$. Only few cases reported the relationship between X-linked AHC and precocious puberty. Wittenberg ${ }^{14)}$ described four male cousins with X-linked AHC in 1981 and they showed varying degree of virilization. Their responses to $\mathrm{GnRH}$ test was prepubertal which suggested gonadotropin-independent precocious puberty (peripheral precocious puberty). Domenice et al. ${ }^{12)}$ reported 2-yearold Brazilian boy with $D A X-1$ mutation whose first clinical manifestation was isosexual gonadotropin-independent precocious puberty. He presented with pubic hair, enlarged penis and testes and advanced bone age. Steroid replacement therapy induced a decrease in testicular size and testosterone levels to the prepubertal range. It was hypothesized that chronic excessive ACTH levels may stimulate the Leydig cells, leading to gonadotropin-independent precocious puberty in some boys.

Gonadotropin-dependent precocious puberty (central precocious puberty) in X-linked AHC patients was also reported ${ }^{4,5,15)}$. Katsumata et al. ${ }^{15)}$ reported the first association of X-linked AHC with presumed central precocious puberty in 1997. The patient was found to have a novel frameshift mutation caused by a 2-nucleotide (AC) insertion at nucleotide 1007 , and duplication of the following 11 nucleotides. At the age of 6 months, he developed pubic hair, and at 1 year and 3 months of age, his mean testicular volume increased to $3.5 \mathrm{~mL}$. He was presumed to have central precocious puberty, based on the increased urinary excretion of gonadotropins and testosterone.

Loke et al. ${ }^{4)}$ reported the first case of central precocious puberty due to complete deletion of $D A X-1$ gene. At 6 years of age, he was noticed to have testicular volumes of $4 \mathrm{~mL}$ bilaterally, a penile length of $8.5 \mathrm{~cm}$ and pubic hair of Tanner stage 2. His response to $\mathrm{GnRH}$ stimulation was pubertal suggestive of gonadotropin-dependent precocious puberty.

Recently, Durmaz et al. ${ }^{16)}$ reported three boys in one large family with novel nonsense Gln208X mutation in the amino terminal domain of the $D A X-1$ gene presented different pubertal status. Two boys developed spontaneous puberty that failed to progress at similar ages, whereas the other boy developed precocious puberty at 10 months of age. The exact mechanism of the mutation on puberty was not known.

Therefore, we need to keep monitoring pubertal status during follow up of the patients with X-linked AHC although the mechanism might be multifactorial which will need further studies.

\section{Conflict of interest}

No potential conflict of interest relevant to this article was reported.

\section{References}

1. Zanaria E, Muscatelli F, Bardoni B, Strom TM, Guioli S, Guo W, et al. An unusual member of the nuclear hormone receptor superfamily responsible for X-linked adrenal hypoplasia congenita. Nature 1994;372:635-41.

2. Walker AP, Chelly J, Love DR, Brush YI, Recan D, Chaussain $\mathrm{JL}$, et al. A YAC contig in Xp21 containing the adrenal hypoplasia congenita and glycerol kinase deficiency genes. Hum Mol Genet 1992;1:579-85.

3. Muscatelli F, Strom TM, Walker AP, Zanaria E, Recan $\mathrm{D}$, Meindl A, et al. Mutations in the DAX-1 gene give rise to both $\mathrm{X}$-linked adrenal hypoplasia congenita and hypogonadotropic hypogonadism. Nature 1994;372:672-6.

4. Loke KY, Poh LK, Lee WW, Lai PS. A case of X-linked adrenal hypoplasia congenita, central precocious puberty and absence of the DAX-1 gene: implications for pubertal regulation. Horm Res 2009;71:298-304.

5. Darcan S, Goksen D, Ozen S, Ozkinay F, Durmaz B, Lalli E. Gonadotropin-dependent precocious puberty in a patient with X-linked adrenal hypoplasia congenita caused by a novel DAX-1 mutation. Horm Res Paediatr 2011;75:153-6.

6. Sikl H. Addison's disease due to congenital hypoplasia of the adrenals in an infant aged 33 days. J Pathol Bacteriol 1948;60:323.

7. Reutens AT, Achermann JC, Ito M, Ito M, Gu WX, Habiby $\mathrm{RL}$, et al. Clinical and functional effects of mutations in the DAX-1 gene in patients with adrenal hypoplasia congenita. J Clin Endocrinol Metab 1999;84:504-11.

8. Hay ID, Smail PJ, Forsyth CC. Familial cytomegalic adrenocortical hypoplasia: an X-linked syndrome of pubertal failure. Arch Dis Child 1981;56:715-21.

9. Habiby RL, Boepple P, Nachtigall L, Sluss PM, Crowley WF Jr, Jameson JL. Adrenal hypoplasia congenita with hypogonadotropic hypogonadism: evidence that DAX1 mutations lead to combined hypothalmic and pituitary defects in gonadotropin production. J Clin Invest 1996;98:1055-62.

10. Seminara SB, Achermann JC, Genel M, Jameson JL, Crowley WF Jr. X-linked adrenal hypoplasia congenita: a mutation in DAX1 expands the phenotypic spectrum in males and females. J Clin Endocrinol Metab 1999;84:45019.

11. Calvari V, Alpigiani MG, Poggi E, Podesta B, Camerino G, Lorini R. X-linked adrenal hypoplasia congenita and hypogonadotropic hypogonadism: report on new mutation of the DAX-1 gene in two siblings. J Endocrinol Invest 2006;29:41-7.

12. Domenice S, Latronico AC, Brito VN, Arnhold IJ, Kok F, 
Mendonca BB. Adrenocorticotropin-dependent precocious puberty of testicular origin in a boy with X-linked adrenal hypoplasia congenita due to a novel mutation in the DAX1 gene. J Clin Endocrinol Metab 2001;86:4068-71.

13. Partsch CJ, Sippell WG. Pathogenesis and epidemiology of precocious puberty. Effects of exogenous oestrogens. Hum Reprod Update 2001;7:292-302.

14. Wittenberg DF. Familial X-linked adrenocortical hypoplasia association with androgenic precocity. Arch Dis Child 1981;56:633-6.

15. Katsumata N, Tanae A, Shinagawa T, Nimura A, Horikawa
$\mathrm{R}$, Tanaka T. Precocious puberty in patient with congenital adrenal hypoplasia congenital (abstract P02-512). In: Proceedings of the 79th Annual Meeting of the Endocrine Society; 1997 June 11-14; Minneapolis, MN, USA. 1997. Chevy Chase, MD; The Endocrine Society; 1997.

16. Durmaz E, Turkkahraman D, Berdeli A, Atan M, Karaguzel G, Akcurin S, et al. A novel DAX-1 mutation presented with precocious puberty and hypogonadotropic hypogonadism in different members of a large pedigree. J Pediatr Endocrinol Metab 2013;26:551-5. 